\title{
RESEARChArTicle
}

\section{Direct and indirect effect of the oat (Avena sativa L.) component characters on the dry forage production}

\author{
R. E. KAKAD, D.R. SAPKAL, A. G. IRATKAR AND G. K. THAKARE
}

\section{SUMMARY}

Oat (Avena sativa L.), one of the important dual purpose crops of the world is grown for food and forage purpose. In India it is exclusively grown as fodder. Sixteen genotypes of oat were grown at the Central Research Farm of Bidhan Chandra Krishi Viswavidyalaya, Gayeshpur, Nadia, W. Bengal in the Rabi season of 2010-11 to estimate the direct and indirect effect of the component characters on the dry matter production. Path analysis carried out considering total dry weight per tiller at 50 per cent flowering as the dependent variable revealed in some characters like plant height at 20 days, fresh weight of per tiller at 40 days, dry weight of leaves per tiller at 40 days, total dry weight per tiller at 40 days and total chlorophyll content in spite of negative direct effect, the correlation value was positive. Again in some characters in spite of significantly positive direct effect, the correlation value was negative e.g. fresh weight of leaves per tiller at 50 per cent flowering. But characters like plant height at 40 days, plant height at 50 per cent flowering, fresh weight per tiller at 50 per cent flowering, dry weight of leaves per tiller at 50 per cent flowering, fresh weight of stem per tiller at 50 per cent flowering, dry weight of stem per tiller at 50 per cent flowering and chlorophyll 'a' both direct effect and correlation were positive. In case of dry weight per plant at 20 days, fresh weight of stem per tiller at 40 day, dry weight of stem per tiller at 40 days, dry weight of flag leaf and chlorophyll ' $b$ ' there was strong positive direct effect but no correlation could be established with dry weight of stem per tiller at 50 per cent flowering.

Key Words : Path analysis, Direct, Indirect effects, Dry forage

How to cite this article : Kakad, R.E., Sapkal, D.R., Iratkar, A.G. and Thakare, G. K. (2017). Study of morphological and genetical variabilities for improving forage production in oat. Internat. J. Plant Sci., 12 (1): 56-60, DOI: 10.15740/HAS/IJPS/12.1/56-60.

Article chronicle : Received : 13.06.2016; Revised : 19.11.2016; Accepted : 15.12.2016

\section{MEMBERS OF THE RESEARCH FORUM}

